\title{
OPEN The analysis of reference genes expression stability in susceptible and resistant Apera spica-venti populations under herbicide treatment
}

\author{
Barbara Wrzesińska ${ }^{1}$, Karolina Kościelniak ${ }^{1}$, Patryk Frąckowiak ${ }^{1}$, Tadeusz Praczyk ${ }^{2}$ \& \\ Aleksandra Obrępalska-Stęplowska ${ }^{1 \bowtie}$
}

Weed resistance to herbicides constitutes a serious problem to world crop production. One of the weeds that are significantly threatening the crops' yield and quality is Apera spica-venti. The target-site resistance (TSR) mechanism of $A$. spica-venti has been widely studied, though, little is known about its non-target-site resistance (NTSR) mechanisms at the molecular level. Molecular examination of NTSR is, to a great extent, based on the expression profiles of selected genes, e.g. those participating in detoxification. However, to obtain reliable results of gene expression analysis, the use of a normalizer is required. The aim of this study was to select the best reference genes in $A$. spica-venti plants of both populations, susceptible and resistant to ALS inhibitor, under treatment with herbicide. Eleven housekeeping genes were chosen for their expression stability assessment. The efficiency correction of raw quantification cycles (Cq) was included in the gene expression stability analyses, which resulted in indicating the TATA-box binding protein (TBP), glyceraldehyde-3phosphate dehydrogenase, cytosolic (GAPC), and peptidyl-prolyl cis-trans isomerase CYP28 (CYP28) genes as the most stably expressed reference genes. The obtained results are of vital importance for future studies on the expression of genes associated with the non-target-site resistance mechanisms in the $A$. spica-venti populations susceptible and resistant to herbicides.

Herbicide resistance is one of the most problematic issues in agriculture. Repeated applications of herbicides in fields created the selection pressure that resulted in the emergence of herbicide-resistant weed populations. One of the commonly occurring weeds belonging to the Poaceae family is silky windgrass (Apera spica-venti L.). It occurs in many countries of central and northern Europe and endangers winter cereal crops, in particular ${ }^{1,2}$. Its spread potential is explained by the adaptation capabilities to inhabit numerous farming environments ${ }^{3,4}$. Silky windgrass populations can easily develop herbicide resistance due to such traits as widespread distribution, cross-pollination, high seed production, and low primary dormancy ${ }^{5}$. One plant can produce up to 16,000 seeds, which are dispersed by water and wind ${ }^{6}$. A. spica-venti has been controlled using acetolactate synthase (ALS) and acetyl-CoA (ACCase) inhibitors, as well as, to a lesser extent, photosystem II inhibitors ${ }^{2}$. However, their long-term use in fields has brought about development of $A$. spica-venti resistance to them.

There are two mechanisms of herbicide resistance, the target-site resistance (TSR) and non-target-site resistance (NTSR). TSR is mainly caused by mutations occurring at the site of herbicide action in the target enzyme, decreasing the affinity of the herbicide active substance. Additionally, less frequently TSR may result from increased expression of the gene being the herbicide target ${ }^{7}$. Currently, in silky windgrass, seven target-site mutations at three positions in the ALS gene are $\mathrm{known}^{5}$. NTSR mechanism encompasses decreased rates of herbicide uptake/translocation/penetration/activation, or increased herbicide metabolism/sequestration ${ }^{7}$. NTSR mechanism involves the induction of expression of a wide variety of genes and gene families, such as encoding cytochrome $\mathrm{P} 450$ monooxygenases (CYP450s), ABC transporters (ABC), glutathione S-transferases $(G S T)$,

${ }^{1}$ Department of Molecular Biology and Biotechnology, Institute of Plant Protection - National Research Institute, Władysława Węgorka 20, 60-318 Poznan, Poland. 2Department of Weed Science and Plant Protection Techniques, Institute of Plant Protection - National Research Institute, Władysława Węgorka 20, 60-318 Poznan, Poland. ${ }^{\square}$ email: ao.steplowska@iorpib.poznan.pl 
glycosyltransferases (GT), esterases, and oxidases $^{8}$. The elevated levels of CYP450s, GT, and GST typically contribute to herbicide detoxification, which is divided in three phases. In the first phase, often mediated by CYP450s, a functional group is added to the herbicide molecule converting it to a more hydrophilic metabolite. Phase II is associated with the conjugation to GSH (mediated by GST) or to glucose (mediated by GT). Finally, in phase III, herbicide metabolites are exported to the vacuole or incorporated into cell wall ${ }^{8,9}$.

The involvement of the mentioned gene families in the NTSR may be studied by the gene expression level analysis. There are several methods to study changes in gene expression, including the quantitative reverse transcription polymerase chain reaction (RT-qPCR), the next-generation sequencing (RNAseq), microarrays, and Northern blotting. RT-qPCR is the most popular and the most commonly used method for the assessment of genes expression level. It is also frequently used for the validation of results obtained in high-throughput analyses. However, to perform a reliable RT-qPCR analysis devoid of the technical and sample variations, a normalization of the expression data using a reference gene or genes is required. The most stably expressed genes should be identified for each type of conditions individually. Both, biotic and abiotic stresses acting on different plant species influence the stability of expression of the potential reference genes and thus the reference gene choice. The studies on reference gene expression stability in weeds belonging to the Poaceae family, Alopecurus myosuroides and Eleusine indica, exposed to herbicide stress have revealed that in the plants subjected to the same stress, different genes exhibited the most stable expressions. Ubiquitin-40S ribosomal protein (UBQ), tubulin (TUB), and glyceraldehyde-3-phosphate dehydrogenase (GAPDH) were the most stably expressed genes in $A$. myosuroides, while ubiquitin-conjugating enzyme $(U B C)$, eukaryotic initiation factor $4 \mathrm{~A}$, and elongation factor 1-alpha $(E F 1 A)$ were indicated as the most stably expressed in $E$. indica ${ }^{10,11}$. Moreover, $T U B$ was identified to show unstable expression in E. indica.

Usually, reference genes used in expression analyses are chosen from those constitutively expressed in all cell types (housekeeping genes, HKGs) because they are required for cell survival ${ }^{12}$. Identification of the most stably expressed genes in the experiments concerning herbicide resistance in different systems is also crucial. Identification of reference genes under treatment with herbicide has been the subject of a number of studies on weed species such as A. myosuroides ${ }^{10}$, E. indica ${ }^{11}$, Lolium rigidum ${ }^{13}$, or Avena fatua ${ }^{14}$. However, no reference gene expression stability analysis has been performed on the herbicide-resistant and susceptible populations of $A$. spica-venti. Moreover, the issue concerning primer efficiency correction of raw quantification cycles $(\mathrm{Cq})$ subjected to statistical analyses of gene expression stability has been usually discounted. The consequences of taking into account the raw Cq values in gene expression stability analyses may result in discrepancies in indicating the most stably expressed genes, relative to the results obtained from analyses of the efficiency corrected data ${ }^{15}$. Therefore, in this study $11 \mathrm{HKGs}$ were chosen for the expression stability analysis in A. spica-venti: actin $(A C T)$, ADP-ribosylation factor 1 (ARF1), peptidyl-prolyl cis-trans isomerase CYP28 (CYP28), EF1A, GAPC, 60S ribosomal protein L23a (RPL23A), Rubisco activase ( $R C A)$, sucrose-phosphate synthase (SPS), TATA-box binding protein $(T B P), U B C$, and $U B Q$. The aim of this study was to determine the best reference genes for determination of selected genes' expression stability profiles in susceptible and resistant $A$. spica-venti plants exposed or not to treatment with herbicide at two time points $(1 \mathrm{~h}$ and $24 \mathrm{~h}$ ). For statistical analysis of the gene expression stability, two series of input data were used: efficiency corrected and non-efficiency corrected Cq values. Additionally, the most stably expressed reference genes in susceptible or resistant plants were also identified.

By employing RT-qPCR and four statistical algorithms for analysis of the efficiency corrected Cq values, the genes: TBP, GAPC, and CYP28 were found among the most stably expressed HKGs in all tested samples, while CYP28, SPS, and GAPC, and, TBP, GAPC, and ACT had the highest expression stability values in susceptible and resistant plants, respectively. Moreover, it was shown that two reference genes were sufficient for the accurate normalization of RT-qPCR results. At the final point of the study, the validation of the ABCC10 and CYP89A2 genes expression, with the use of $T B P$ and $G A P C$, revealed the involvement of these detoxification-related genes in A. spica-venti response to a herbicide belonging to the sulfonamide group.

\section{Results}

Plant populations selection for analysis of the expression stability of housekeeping genes. Eleven populations (two susceptible and nine resistant) were examined in order to determine ED50 (effective dose of active ingredient (ai) causing a 50\% reduction in plant biomass). In the susceptible populations, ED50 was lower than $1 / 16 \mathrm{~N}$ dose $\left(\mathrm{N}\right.$ - the maximal recommended dose of the herbicide $\left(120 \mathrm{~g} \mathrm{ha}^{-1}\right.$, i.e. $9 \mathrm{~g} \mathrm{ha}^{-1}$ of ai)) (Table S1). For four out of the nine resistant populations the ED50 values were higher than $32 \mathrm{~N}$ dose of the herbicide. In order to choose A. spica-venti populations to be subjected to HKGs stability analysis, plants from the populations resistant and susceptible to pyroxsulam were examined for the absence of mutations in the $A L S$ sequence. ALS sequence analysis permitted selection of two susceptible and two resistant $A$. spica-venti populations without known mutations conferring the resistance. Single mutations were found, however, they were present in both susceptible and resistant plants, or the interdomain region of ALS.

RT-qPCR primer specificity and efficiency. In order to choose the most reliable reference genes in susceptible and resistant to ALS inhibitors plants of A. spica-venti exposed to treatment with herbicide, 11 candidate HKGs were selected for the expression stability analysis. These candidates were the primary metabolism genes frequently used as reference ones in other weeds species and were indicated as stable in other plants exposed to different abiotic stresses. The specificity of the primers used was confirmed by a single peak of melting curves (Fig. 1) and agarose gel electrophoresis (Fig. 2). The sequences of RT-qPCR products were compared to the previously published A. spica-venti transcriptome data (NCBI Gene Expression Omnibus GSE86989) ${ }^{16}$ showing high identity to the corresponding genes in the transcriptome. These sequences were deposited in the GenBank database (accession numbers provided in Table 1). To confirm the similarity of the obtained sequences to the 

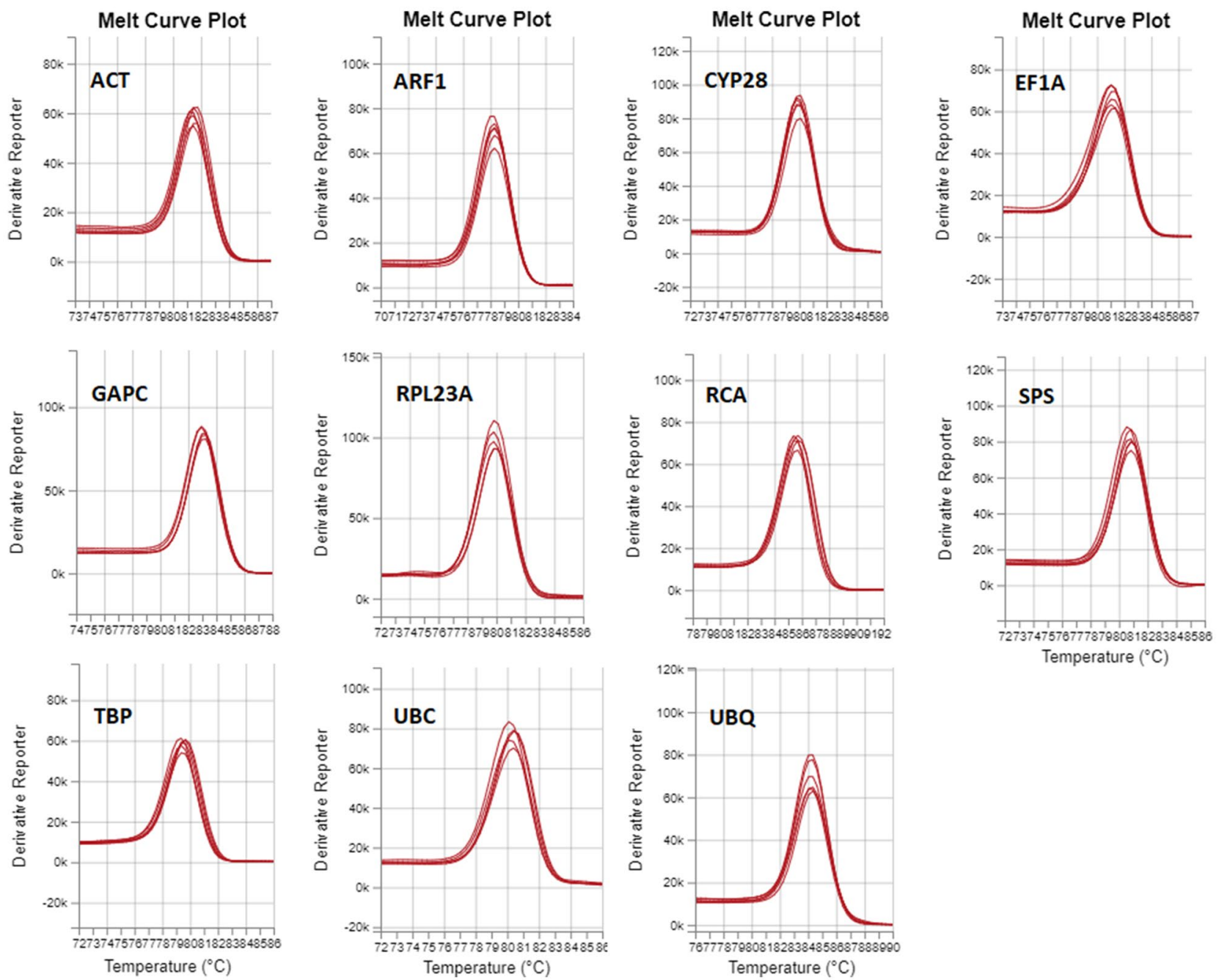

Figure 1. Melting curve plots for candidate reference genes.

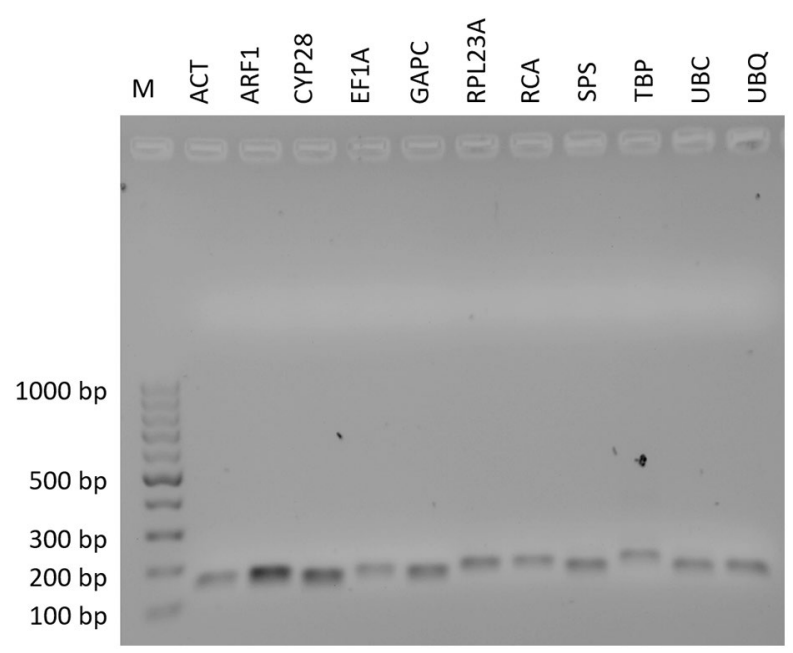

Figure 2. RT-qPCR amplification products of $A$. spica-venti candidate reference genes. $M$ DNA ladder, $b p$ base pairs. 


\begin{tabular}{|c|c|c|c|c|c|c|c|}
\hline Analysis & Gene & $\begin{array}{l}\text { Accession numbers of } \\
\text { the sequences in } A \text {. spica- } \\
\text { venti transcriptome/ } \\
\text { sequenced in this } \\
\text { study and deposited in } \\
\text { GenBank }\end{array}$ & Primer sequence $\left(5^{\prime}-3^{\prime}\right)$ & Amplicon length (bp) & $\begin{array}{l}\text { Annealing temperature } \\
\left({ }^{\circ} \mathrm{C}\right)\end{array}$ & RSq & PCR efficiency (\%) \\
\hline \multirow{22}{*}{$\begin{array}{l}\text { Reference genes expres- } \\
\text { sion stability analysis }\end{array}$} & \multirow{2}{*}{ ACT } & $\begin{array}{l}\text { TRINITY_DN132310_ } \\
\text { c0_g1_i1|m.143952 }\end{array}$ & $\begin{array}{l}\text { F: CGCTTATGTTGC } \\
\text { CCTTGATT }\end{array}$ & \multirow[b]{2}{*}{151} & \multirow[b]{2}{*}{64} & \multirow{2}{*}{0.994} & \multirow{2}{*}{91.4} \\
\hline & & MW712586 & $\begin{array}{l}\text { R: AAGAGATGGCTG } \\
\text { GAAAAGCA }\end{array}$ & & & & \\
\hline & \multirow{2}{*}{ ARF1 } & \begin{tabular}{|l|} 
TRINITY_DN237260_ \\
c0_g1_i2|m.37134
\end{tabular} & $\begin{array}{l}\text { F: GTTCCAACTGTG } \\
\text { GGGCTTAAT }\end{array}$ & \multirow{2}{*}{157} & \multirow{2}{*}{60} & \multirow{2}{*}{0.998} & \multirow{2}{*}{94.8} \\
\hline & & MW712587 & $\begin{array}{l}\text { R: ATGCAGAGGCAG } \\
\text { AGTCGATAA }\end{array}$ & & & & \\
\hline & \multirow{2}{*}{ CYP28 } & $\begin{array}{l}\text { TRINITY_DN244654_ } \\
\text { c2_g6_i1|m.54263 }\end{array}$ & $\begin{array}{l}\text { F: GTCCACCTCCAC } \\
\text { AATTGACAC }\end{array}$ & \multirow{2}{*}{146} & \multirow{2}{*}{62} & \multirow{2}{*}{0.997} & \multirow{2}{*}{99.9} \\
\hline & & MW712588 & $\begin{array}{l}\text { R: CAAAGACTACAC } \\
\text { GGCCAAGAG }\end{array}$ & & & & \\
\hline & \multirow{2}{*}{ EF1A } & $\begin{array}{l}\text { TRINITY_DN251778_ } \\
\text { c2_g5_i3|m.44674 }\end{array}$ & $\begin{array}{l}\text { F: CCGAGCGTGAGA } \\
\text { GAGGTATC }\end{array}$ & \multirow{2}{*}{157} & \multirow{2}{*}{56} & \multirow{2}{*}{0.998} & \multirow{2}{*}{108.2} \\
\hline & & MW712589 & $\begin{array}{l}\text { R: TCAATGATGAGC } \\
\text { ACAGCACA }\end{array}$ & & & & \\
\hline & \multirow{2}{*}{ GAPC } & $\begin{array}{l}\text { TRINITY_DN238590_ } \\
\text { c0_g1_i2|m.43942 }\end{array}$ & $\begin{array}{l}\text { F: CAGTCACTGTCT } \\
\text { TCGGTGTCA } \\
\end{array}$ & \multirow{2}{*}{151} & \multirow{2}{*}{58} & \multirow{2}{*}{0.999} & \multirow{2}{*}{106.7} \\
\hline & & MW712590 & $\begin{array}{l}\text { R: GCAGAGATGACC } \\
\text { ACCTTCTTG }\end{array}$ & & & & \\
\hline & \multirow{2}{*}{ RPL23A } & $\begin{array}{l}\text { TRINITY_DN242121_- } \\
\text { c1_g10_i1|m.107926 }\end{array}$ & $\begin{array}{l}\text { F: AAGTACCCCAGG } \\
\text { ATCAGCACT }\end{array}$ & \multirow{2}{*}{166} & \multirow{2}{*}{60} & \multirow{2}{*}{0.999} & \multirow{2}{*}{88.2} \\
\hline & & MW712591 & $\begin{array}{l}\text { R: TGACAGCAGCCT } \\
\text { TGATCTTCT }\end{array}$ & & & & \\
\hline & \multirow{2}{*}{ RCA } & $\begin{array}{l}\text { TRINITY_DN254390_ } \\
\text { c0_g3_i5|m.45789 }\end{array}$ & $\begin{array}{l}\text { F: ACTACCATGGCA } \\
\text { AGAGCTTCA }\end{array}$ & & & & \\
\hline & & MW712592 & $\begin{array}{l}\text { R: GAAGAGGGAGTC } \\
\text { CACGATAC }\end{array}$ & 167 & 54 & 0.999 & 105.6 \\
\hline & SPS & $\begin{array}{l}\text { TRINITY_DN256108_ } \\
\text { c2_g8_i1|m.2492 }\end{array}$ & $\begin{array}{l}\text { F: CATGCAGATGTC } \\
\text { CAAGGTTCT }\end{array}$ & 152 & 62 & 0.997 & 99.8 \\
\hline & & MW712593 & $\begin{array}{l}\text { R: GAGAATGGCCTG } \\
\text { TGAATACCA }\end{array}$ & & & & \\
\hline & TRP & $\begin{array}{l}\text { TRINITY_DN243731_ } \\
\text { c0_g18_i1|m.150479 }\end{array}$ & $\begin{array}{l}\text { F: TCGTTGGCTCTT } \\
\text { GTGATGTC }\end{array}$ & 175 & 64 & 0990 & 005 \\
\hline & IDP & MW712594 & $\begin{array}{l}\text { R: TTTGCTCCGGTC } \\
\text { AAGACAAT }\end{array}$ & $1 / 5$ & 04 & 0.999 & 90.3 \\
\hline & UPR & $\begin{array}{l}\text { TRINITY_DN257614_ } \\
\text { c2_g3_i2|m.4201 }\end{array}$ & $\begin{array}{l}\text { F: TGGTGCATGTGA } \\
\text { ACTGGATAA }\end{array}$ & 140 & 60 & 0009 & 026 \\
\hline & UBC & MW712595 & $\begin{array}{l}\text { R: AGACAGAGTGCA } \\
\text { CCAATCACC }\end{array}$ & 149 & 60 & 0.998 & 92.6 \\
\hline & (1DO & $\begin{array}{l}\text { TRINITY_DN236450_ } \\
\text { c0_g17_i1|m.156536 }\end{array}$ & $\begin{array}{l}\text { F: CAACATCCAGAA } \\
\text { GGAGTCCAC }\end{array}$ & $1-6$ & 60 & C 0000 & 006 \\
\hline & UBQ & MW712596 & $\begin{array}{l}\text { R: CCGTCGTCGACC } \\
\text { TTATAGAAC }\end{array}$ & 156 & 60 & 0.998 & 98.6 \\
\hline & $\mathrm{ABCC} 10$ & $\begin{array}{l}\text { TRINITY_DN231466_ } \\
\text { c1_g3_i1|m.91733 }\end{array}$ & $\begin{array}{l}\text { F: TCTTGGTGTGGC } \\
\text { GTTTGTTC } \\
\end{array}$ & 113 & 60 & 0998 & 1134 \\
\hline Velidatio & & MW712597 & $\begin{array}{l}\text { R: CCTTGATGGTGA } \\
\text { TCGTCTGCT }\end{array}$ & & & & \\
\hline vantuation & CYPe? & $\begin{array}{l}\text { TRINITY_DN252745_ } \\
\text { c0_g2_i2|m.101768 }\end{array}$ & $\begin{array}{l}\text { F: GGACACTCTGCT } \\
\text { CGACATCA }\end{array}$ & & 60 & & \\
\hline & CYP82A2 & MW712598 & $\begin{array}{l}\text { R: AGAGCTTGTGCT } \\
\text { GGATGGAT }\end{array}$ & 170 & 60 & 0.998 & 103.0 \\
\hline
\end{tabular}

Table 1. Primer sequences for RT-qPCR used in this study. $R S q$ R-squared value for standard curve.

selected genes, the latter were blasted in the following databases: NCBI blastn and UniProt blastp, as well as, against model plant species Arabidopsis thaliana and Brachypodium distachyon. The results with the highest scores are presented in Table S2.

The analysis of standard curves resulted in the amplification efficiency ranging from $88.2 \%(R P L 23 A)$ to $108.2 \%$ (EF1A), while the regression coefficient varied from 0.994 (ACT) to 0.999 (GAPC, RPL23A, RCA, and $T B P$ ) (Table 1). The distribution of Cq values revealed the highest expression of $R C A$ with the mean Cq value of 18.82, while the lowest mean Cq value was observed for ARF1 (27.19) (Fig. 3). The lowest Cq range (5.11 cycles) was detected for the TBP, whereas the greatest discrepancy in Cq values (11.15) was observed for EF1A. 


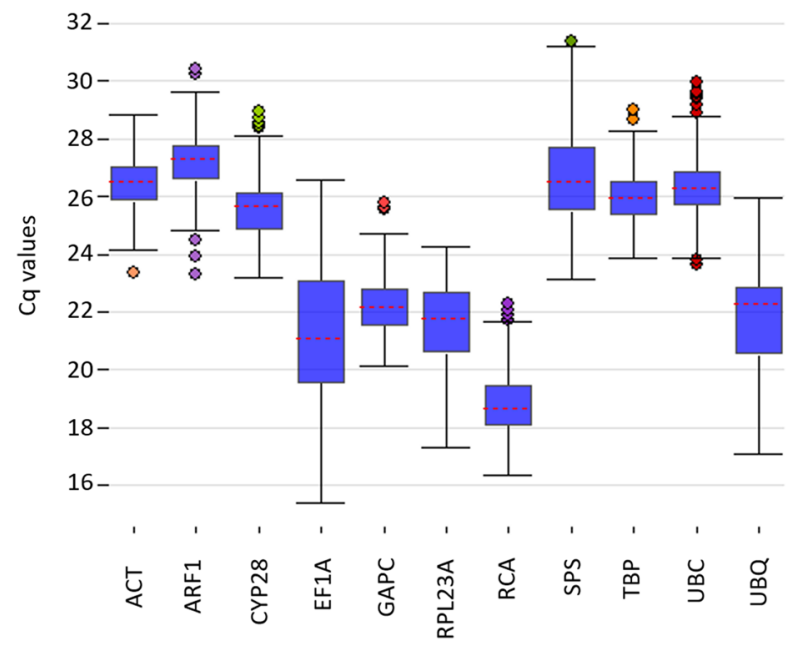

Figure 3. Distribution of the raw RT-qPCR quantification cycle $(\mathrm{Cq})$ values for the candidate reference genes.

Analysis of the candidate reference genes expression stability. The HKGs expression stability analyses were performed with the following datasets: the first one consisted of data taken from all samples, the second one-the data obtained for the samples from susceptible plants, and the third one-the data collected for the samples from resistant plants. Four statistical tools were used to conduct the analysis: geNorm ${ }^{17}$, BestKeeper ${ }^{18}$, NormFinder ${ }^{19}$, and $\Delta \mathrm{C}_{t}^{20}$. To gain a comprehensive summary of the results, RefFinder software (https://www.heartcure.com.au/reffinder) was used.

Most of the gene expression stability analysis softwares omit the fact that not every primer pair and reaction conditions ensure $100 \%$ efficiency in RT-qPCR. The use of qPCR efficiency corrected Cq values in statistical analyses of the most stably expressed genes impacts the final expression stability ranking, which may result in selection of different sets of reference genes for normalization. Therefore, the efficiency correction was applied to the raw $\mathrm{Cq}$ values.

Candidate reference genes expression stability analysis in all samples indicated that TBP, GAPC, and CYP28 show the most stable expression under tested conditions. The first analysis, performed with the geNorm software, using Bioconductor "NormqPCR" package in R software, indicated that the first three of the most stably expressed genes were $T B P, A R F 1$, and $G A P C$, while the genes with the least stable expression were-EF1A, $U B Q$, and RPL23A (Table 2). The last three genes also exhibited unstable expression according to BestKeeper and NormFinder analyses. The genes found to be the most stably expressed by BestKeeper were TBP, ACT, and GAPC, whereas the ones $C Y P 28, T B P$, and GAPC were indicated as the most stably expressed by NormFinder. Similarly, the $\triangle \mathrm{Ct}$ method pinpointed $C Y P 28, T B P$, and GAPC to have the highest expression stability, contrary to $R C A$, $E F 1 A$, and RPL23A that were classified as the least stably expressed. The general ranking obtained from RefFinder analysis indicated TBP, GAPC, and CYP28 as the reference genes with the most stable expression in the plants susceptible and resistant to pyroxsulam, and EF1A, UBQ, and RPL23A as the least stably expressed ones.

Analysis of the reference genes expression stability separately for the pyroxsulam susceptible and resistant plants indicated that TBP was among the most stably expressed genes in both types of samples. The same methods were used in the analyses of HKGs expression stability, separately in the plants showing the susceptibility or resistance to sulfonamide herbicides.

In the susceptible plants (Table 2), the genes exhibiting the highest expression stability were as follows: CYP28, SPS, and TBP (according to geNorm); TBP, ACT, and SPS (according to BestKeeper); CYP28, SPS, and GAPC (according to NormFinder); TBP, CYP28, and $A C T$ (according to $\triangle \mathrm{Ct}$ method). The least stably expressed genes were: $E F 1 A, U B Q$, and RPL23A (according to geNorm and BestKeeper); EF1A, UBC, and RPL23A (according to NormFinder); $R C A, U B Q$, and RPL23A (according to $\triangle \mathrm{Ct}$ method). The comprehensive ranking established using RefFinder showed that $C Y P 28, S P S$, and $T B P$ were characterized by the highest expression stability values, and $E F 1 A, R P L 23 A$, and $U B Q$ were indicated to have unstable expression.

In the resistant plants (Table 2), the genes classified to be the most stably expressed were as follows: $T B P$, $A R F 1$, and $A C T$ (according to geNorm); GAPC, ACT, and TBP (according to BestKeeper); GAPC, TBP, and $C Y P 28$ (according to NormFinder); CYP28, TBP, and GAPC (according to $\triangle \mathrm{Ct}$ method). The genes identified as the least stably expressed were: EF1A, RPL23A, and UBQ (according to geNorm); EF1A, RPL23A, and SPS (according to BestKeeper); EF1A, SPS, and RPL23A (according to NormFinder); RCA, EF1A, and ARF1 (according to $\triangle \mathrm{Ct}$ method). RefFinder analysis indicated $G A P C, T B P$, and $A R F 1$ as the best reference genes with the most stable expression, while EF1A, RPL23A, and SPS showed the least stability in their expression. 


\begin{tabular}{|c|c|c|c|c|c|c|c|c|c|c|c|c|}
\hline \multirow[b]{2}{*}{ Analysis } & \multirow[b]{2}{*}{ Sample data } & \multicolumn{11}{|c|}{ Genes expression stability } \\
\hline & & \multicolumn{5}{|c|}{ Most stable } & \multicolumn{6}{|c|}{ Less stable } \\
\hline \multirow{6}{*}{ GeNorm (M value) } & \multirow{2}{*}{ All samples } & TBP & ARF1 & GAPC & $A C T$ & CYP28 & $U B C$ & SPS & $R C A$ & RPL23A & $U B Q$ & $E F 1 A$ \\
\hline & & 0.044 & 0.044 & 0.044 & 0.046 & 0.050 & 0.053 & 0.056 & 0.059 & 0.070 & 0.076 & 0.087 \\
\hline & \multirow{2}{*}{ Susceptible } & CYP28 & SPS & $T B P$ & $A C T$ & GAPC & ARF1 & $U B C$ & $R C A$ & RPL23A & $U B Q$ & $E F 1 A$ \\
\hline & & 0.034 & 0.034 & 0.042 & 0.044 & 0.046 & 0.049 & 0.052 & 0.056 & 0.070 & 0.078 & 0.086 \\
\hline & \multirow{2}{*}{ Resistant } & $T B P$ & ARF1 & $A C T$ & GAPC & CYP28 & $U B C$ & SPS & $R C A$ & $U B Q$ & RPL23A & $E F 1 A$ \\
\hline & & 0.034 & 0.034 & 0.034 & 0.035 & 0.038 & 0.041 & 0.045 & 0.048 & 0.053 & 0.058 & 0.068 \\
\hline \multirow{6}{*}{ BestKeeper (SD) } & \multirow{2}{*}{ All samples } & $T B P$ & $A C T$ & GAPC & ARF1 & CYP28 & $R C A$ & $U B C$ & SPS & RPL23A & $U B Q$ & $E F 1 A$ \\
\hline & & 0.705 & 0.795 & 0.801 & 0.869 & 0.894 & 0.926 & 0.955 & 1.220 & 1.338 & 1.409 & 1.918 \\
\hline & \multirow{2}{*}{ Susceptible } & TBP & $A C T$ & SPS & GAPC & $R C A$ & CYP28 & ARF1 & $U B C$ & RPL23A & $U B Q$ & EF1A \\
\hline & & 0.694 & 0.716 & 0.847 & 0.878 & 0.907 & 0.926 & 0.982 & 1.063 & 1.617 & 1.653 & 1.874 \\
\hline & \multirow{2}{*}{ Resistant } & GAPC & $A C T$ & TBP & ARF1 & CYP28 & $R C A$ & $U B C$ & $U B Q$ & SPS & RPL23A & EF1A \\
\hline & & 0.690 & 0.698 & 0.716 & 0.736 & 0.777 & 0.790 & 0.870 & 1.038 & 1.049 & 1.062 & 1.526 \\
\hline \multirow{6}{*}{ NormFinder (SD) } & \multirow{2}{*}{ All samples } & CYP28 & TBP & GAPC & ARF1 & $R C A$ & $A C T$ & SPS & $U B C$ & RPL23A & $U B Q$ & $E F 1 A$ \\
\hline & & 0.530 & 0.578 & 0.617 & 0.650 & 0.899 & 0.936 & 0.996 & 1.015 & 1.120 & 1.219 & 1.775 \\
\hline & \multirow{2}{*}{ Susceptible } & CYP28 & SPS & GAPC & TBP & ARF1 & $A C T$ & $R C A$ & $U B Q$ & RPL23A & $U B C$ & EF1A \\
\hline & & 0.438 & 0.558 & 0.682 & 0.685 & 0.745 & 0.788 & 0.967 & 1.250 & 1.252 & 1.255 & 1.625 \\
\hline & \multirow{2}{*}{ Resistant } & GAPC & TBP & CYP28 & ARF1 & $A C T$ & $U B Q$ & $U B C$ & $R C A$ & RPL23A & SPS & EF1A \\
\hline & & 0.350 & 0.402 & 0.529 & 0.555 & 0.684 & 0.696 & 0.740 & 0.753 & 0.940 & 0.948 & 1.305 \\
\hline \multirow{6}{*}{$\Delta \mathrm{CT}($ mean $\mathrm{SD})$} & \multirow{2}{*}{ All samples } & CYP28 & TBP & GAPC & $U B C$ & $A C T$ & SPS & $U B Q$ & ARF1 & RPL23A & EF1A & $R C A$ \\
\hline & & 1.683 & 1.711 & 1.878 & 1.896 & 1.910 & 1.991 & 2.056 & 2.079 & 2.094 & 2.439 & 3.044 \\
\hline & \multirow{2}{*}{ Susceptible } & $T B P$ & CYP28 & $A C T$ & $U B C$ & GAPC & $E F 1 A$ & ARF1 & SPS & RPL23A & $U B Q$ & $R C A$ \\
\hline & & 1.460 & 1.467 & 1.500 & 1.670 & 1.700 & 1.772 & 1.800 & 1.804 & 1.840 & 1.865 & 2.622 \\
\hline & \multirow{2}{*}{ Resistant } & CYP28 & TBP & GAPC & SPS & $U B C$ & $U B Q$ & $A C T$ & RPL23A & ARF1 & $E F 1 A$ & $R C A$ \\
\hline & & 1.388 & 1.458 & 1.516 & 1.525 & 1.529 & 1.545 & 1.700 & 1.723 & 1.814 & 2.217 & 2.813 \\
\hline \multirow{6}{*}{ RefFinder (Geomean) } & \multirow{2}{*}{ All samples } & TBP & GAPC & CYP28 & ARF1 & $A C T$ & $R C A$ & UBC & SPS & RPL23A & $U B Q$ & EF1A \\
\hline & & 1.190 & 2.280 & 2.510 & 3.720 & 4.740 & 5.230 & 6.960 & 7.740 & 9.000 & 10.000 & 11.000 \\
\hline & \multirow{2}{*}{ Susceptible } & CYP28 & SPS & TBP & GAPC & $A C T$ & ARF1 & $R C A$ & $U B C$ & $U B Q$ & RPL23A & EF1A \\
\hline & & 1.570 & 1.860 & 2.830 & 3.220 & 4.160 & 6.190 & 6.190 & 8.460 & 8.970 & 9.490 & 11.000 \\
\hline & \multirow{2}{*}{ Resistant } & GAPC & TBP & ARF1 & $A C T$ & CYP28 & $U B C$ & $R C A$ & $U B Q$ & SPS & RPL23A & $E F 1 A$ \\
\hline & & 1.000 & 2.450 & 2.830 & 3.760 & 3.870 & 6.480 & 6.960 & 7.670 & 8.970 & 9.740 & 11.000 \\
\hline
\end{tabular}

Table 2. Expression stability ranking of eleven candidate genes in Apera spica-venti plants resistant and susceptible to pyroxsulam. The input data for the geNorm, BestKeeper, $\Delta \mathrm{C}_{t}$, and RefFinder calculations were the raw $\mathrm{Cq}$ values.

Statistical analyses of efficiency adjusted Cq values has changed the positions of the candidate reference genes in the expression stability ranking. The efficiency correction to the raw Cq values obtained from RT-qPCR was applied using the GenEx software. The values of efficiency used are given in Table 1. The gene expression stability analysis using the corrected Cq values was performed with all statistical methods used in the previous analyses namely: geNorm, BestKeeper, NormFinder, $\Delta \mathrm{Ct}$, and RefFinder. This approach resulted in differences in the gene expression stability ranking (Table 3 ). Then, two genes expression stability rankings based on the data resulting from analyses of efficiency corrected $\mathrm{Cq}$ and non-corrected Cq were compared. No differences in the results obtained from geNorm analyses were observed. The results of the BestKeeper and NormFinder softwares revealed the changes in 39\% (13/33) and 33\% (11/33) of HKGs positions, respectively. The biggest discrepancies in the rankings were observed in the results obtained by the $\Delta$ Ct method, with $73 \%(24 / 33)$ of changes in genes positions. The comprehensive ranking obtained by RefFinder showed that 45\% (15/33) HKGs positions were altered.

In all samples analyzed (Table 3), the three most stably expressed genes taking into account the efficiency correction were as follows: $A R F 1, T B P$, and GAPC (according to geNorm); TBP, ACT, and ARF1 (according to BestKeeper); CYP28, TBP, and ARF1 (according to NormFinder); TBP, GAPC, and ACT (according to $\triangle \mathrm{Ct}$ method); TBP, CYP28, and GAPC (according to RefFinder). The ranking of the least stably expressed genes changed only according to the results of $\triangle \mathrm{Ct}$ method and comprised $R C A, R P L 3 A$, and $E F 1 A$.

In the samples collected from the susceptible plants, the three most stably expressed genes taking into account the efficiency correction were as follows: CYP28, SPS, and TBP (according to geNorm); TBP, ACT, and SPS (according to BestKeeper); CYP28, SPS, and TBP (according to NormFinder); TBP, ACT, and GAPC (according to $\triangle \mathrm{Ct}$ method); CYP28, SPS, and GAPC (according to RefFinder). Changes in the order of the unstably expressed genes were found in the results obtained from NormFinder (for genes $E F 1 A, U B Q$, and $U B C$ ), $\triangle \mathrm{Ct}$ (for RPL23A, $R C A$, and SPS) and RefFinder (for EF1A, UBQ, and RPL23A). 


\begin{tabular}{|c|c|c|c|c|c|c|c|c|c|c|c|c|}
\hline \multirow[b]{2}{*}{ Analysis } & \multirow[b]{2}{*}{ Sample data } & \multicolumn{11}{|c|}{ Genes expression stability } \\
\hline & & \multicolumn{5}{|c|}{ Most stable } & \multicolumn{6}{|c|}{ Less stable } \\
\hline \multirow{6}{*}{ geNORM (M value) } & \multirow{2}{*}{ All samples } & ARF1 & TBP & GAPC & $A C T$ & CYP28 & $U B C$ & SPS & $R C A$ & RPL23A & $U B Q$ & $E F 1 A$ \\
\hline & & 0.044 & 0.044 & 0.044 & 0.046 & 0.050 & 0.053 & 0.056 & 0.059 & 0.070 & 0.076 & 0.087 \\
\hline & \multirow{2}{*}{ Susceptible } & CYP28 & SPS & TBP & $A C T$ & GAPC & ARF1 & $U B C$ & $R C A$ & RPL23A & $U B Q$ & $E F 1 A$ \\
\hline & & 0.034 & 0.034 & 0.042 & 0.044 & 0.046 & 0.049 & 0.052 & 0.056 & 0.070 & 0.078 & 0.086 \\
\hline & \multirow{2}{*}{ Resistant } & TBP & ARF1 & $A C T$ & GAPC & CYP28 & $U B C$ & SPS & $R C A$ & $U B Q$ & RPL23A & $E F 1 A$ \\
\hline & & 0.034 & 0.034 & 0.034 & 0.035 & 0.038 & 0.041 & 0.045 & 0.048 & 0.053 & 0.058 & 0.068 \\
\hline \multirow{6}{*}{ BestKeeper (SD) } & \multirow{2}{*}{ All samples } & TBP & $A C T$ & ARF1 & GAPC & CYP28 & $U B C$ & $R C A$ & SPS & RPL23A & $U B Q$ & EF1A \\
\hline & & 0.655 & 0.744 & 0.836 & 0.839 & 0.893 & 0.903 & 0.963 & 1.218 & 1.221 & 1.395 & 2.029 \\
\hline & \multirow{2}{*}{ Susceptible } & $T B P$ & $A C T$ & SPS & GAPC & CYP28 & $R C A$ & ARF1 & $U B C$ & RPL23A & $U B Q$ & $E F 1 A$ \\
\hline & & 0.645 & 0.671 & 0.846 & 0.920 & 0.926 & 0.943 & 0.945 & 1.005 & 1.475 & 1.637 & 1.982 \\
\hline & \multirow{2}{*}{ Resistant } & $A C T$ & $T B P$ & ARF1 & GAPC & CYP28 & $R C A$ & $U B C$ & RPL23A & $U B Q$ & SPS & $E F 1 A$ \\
\hline & & 0.653 & 0.665 & 0.708 & 0.722 & 0.777 & 0.822 & 0.822 & 0.969 & 1.028 & 1.047 & 1.614 \\
\hline \multirow{6}{*}{ NormFinder (SD) } & \multirow{2}{*}{ All samples } & CYP28 & TBP & ARF1 & GAPC & $A C T$ & $R C A$ & $U B C$ & SPS & RPL23A & $U B Q$ & EF1A \\
\hline & & 0.520 & 0.576 & 0.631 & 0.634 & 0.913 & 0.919 & 0.967 & 0.987 & 1.004 & 1.213 & 1.920 \\
\hline & \multirow{2}{*}{ Susceptible } & CYP28 & SPS & TBP & GAPC & ARF1 & $A C T$ & $R C A$ & RPL23A & $U B C$ & $U B Q$ & EF1A \\
\hline & & 0.435 & 0.553 & 0.680 & 0.704 & 0.715 & 0.774 & 0.984 & 1.104 & 1.199 & 1.239 & 1.768 \\
\hline & \multirow{2}{*}{ Resistant } & GAPC & TBP & CYP28 & ARF1 & $A C T$ & UBQ & $U B C$ & $R C A$ & RPL23A & SPS & EF1A \\
\hline & & 0.341 & 0.395 & 0.522 & 0.547 & 0.668 & 0.688 & 0.703 & 0.772 & 0.854 & 0.946 & 1.426 \\
\hline \multirow{6}{*}{$\Delta \mathrm{CT}($ mean $\mathrm{SD})$} & \multirow{2}{*}{ All samples } & TBP & GAPC & $A C T$ & $U B C$ & CYP28 & ARF1 & $U B Q$ & SPS & EF1A & RPL23A & $R C A$ \\
\hline & & 1.421 & 1.475 & 1.563 & 1.593 & 1.641 & 1.827 & 1.917 & 2.055 & 2.090 & 2.476 & 2.492 \\
\hline & \multirow{2}{*}{ Susceptible } & TBP & $A C T$ & GAPC & $U B C$ & CYP28 & EF1A & ARF1 & $U B Q$ & SPS & $R C A$ & RPL23A \\
\hline & & 1.238 & 1.266 & 1.315 & 1.415 & 1.497 & 1.556 & 1.586 & 1.790 & 1.960 & 2.115 & 2.288 \\
\hline & \multirow{2}{*}{ Resistant } & $T B P$ & GAPC & $U B C$ & $A C T$ & CYP28 & $U B Q$ & SPS & ARF1 & $E F 1 A$ & RPL23A & $R C A$ \\
\hline & & 1.118 & 1.137 & 1.202 & 1.262 & 1.266 & 1.353 & 1.515 & 1.551 & 1.656 & 2.052 & 2.250 \\
\hline \multirow{6}{*}{ RefFinder (Geomean) } & \multirow{2}{*}{ All samples } & TBP & CYP28 & GAPC & ARF1 & $A C T$ & $R C A$ & $U B C$ & SPS & RPL23A & UBQ & EF1A \\
\hline & & 1.410 & 1.860 & 2.280 & 4.680 & 4.700 & 5.730 & 5.790 & 7.740 & 9.000 & 10.000 & 11.000 \\
\hline & \multirow{2}{*}{ Susceptible } & CYP28 & SPS & GAPC & TBP & $A C T$ & $R C A$ & ARF1 & $U B C$ & RPL23A & $U B Q$ & EF1A \\
\hline & & 1.500 & 1.860 & 3.220 & 3.360 & 3.980 & 6.190 & 6.320 & 7.420 & 8.740 & 10.000 & 11.000 \\
\hline & \multirow{2}{*}{ Resistant } & TBP & GAPC & $A C T$ & CYP28 & ARF1 & $U B C$ & $R C A$ & $U B Q$ & RPL23A & SPS & EF1A \\
\hline & & 1.190 & 1.860 & 2.940 & 3.870 & 4.000 & 6.480 & 7.200 & 7.640 & 8.970 & 9.460 & 11.000 \\
\hline
\end{tabular}

Table 3. Expression stability ranking of eleven candidate genes in Apera spica-venti plants resistant and susceptible to pyroxsulam. The input data consisting for geNorm, BestKeeper, NormFinder, $\Delta \mathrm{Ct}$, and RefFinder calculations of were Cq values after efficiency correction.

The greatest differences in the initial three positions were found in the results obtained for the samples harvested from the resistant plants. The most stably expressed genes after efficiency correction ranked as follows: $T B P, A R F 1$, and $A C T$ (according to geNorm); $A C T, T B P$, and $A R F 1$ (according to BestKeeper); GAPC, TBP, and $C Y P 28$ (according to NormFinder); TBP, GAPC, and UBC (according to $\triangle \mathrm{Ct}$ method); TBP, GAPC, and ACT (according to RefFinder). However, the positions of the most as well as the least stably expressed genes were unaltered in the NormFinder ranking. The unstably expressed genes in the rankings were changed accordingly to the following methods: BestKeeper (EF1A, SPS, and UBQ), $\triangle \mathrm{Ct}$ method (RCA, RPL23A, and EF1A), and RefFinder (EF1A, SPS, and RPL23A).

Two reference genes are required for the normalization of target genes expression results. Pairwise variation $\left(V_{n / n+1}\right)$ between the two sequential normalization factors $\left(\mathrm{NF}_{n}\right.$ and $\left.\mathrm{NF}_{\mathrm{n}+1}\right)$ was calculated using geNorm. The threshold value of pairwise variation $(\mathrm{V})$ below 0.15 indicates the minimum number of reference genes needed for the normalization of the target gene. In all samples collected from the plants susceptible and resistant to the herbicide, the target gene is required to be normalized using two reference genes. The $\mathrm{V}_{2 / 3}$ value was lower than 0.15 , regardless of the experimental variant (Fig. 4).

Validation of the selected reference genes revealed the constitutive $A B C C 10$ and CYP89A2 up-regulation of their expression in plants resistant to pyroxsulam. $A B C$ transporters as well as CYP450s are found to be involved in the metabolism-based NTSR to ALS inhibitors ${ }^{21}$. ABCC10 was highly expressed in Myosoton aquaticum plants resistant to ALS inhibitor ${ }^{22}$, while CYP89A2 was identified to confer metabolism-based diclofop resistance in Lolium rigidum ${ }^{23}$. To normalize the ABCC10 and CYP89A2 expressions, the selected pairs of reference genes were chosen according to the efficiency corrected results. The analysis was performed using the most stably (TBP and GAPC) and the least stably ( $E F 1 A$ and $U B Q$ ) expressed HKGs in 


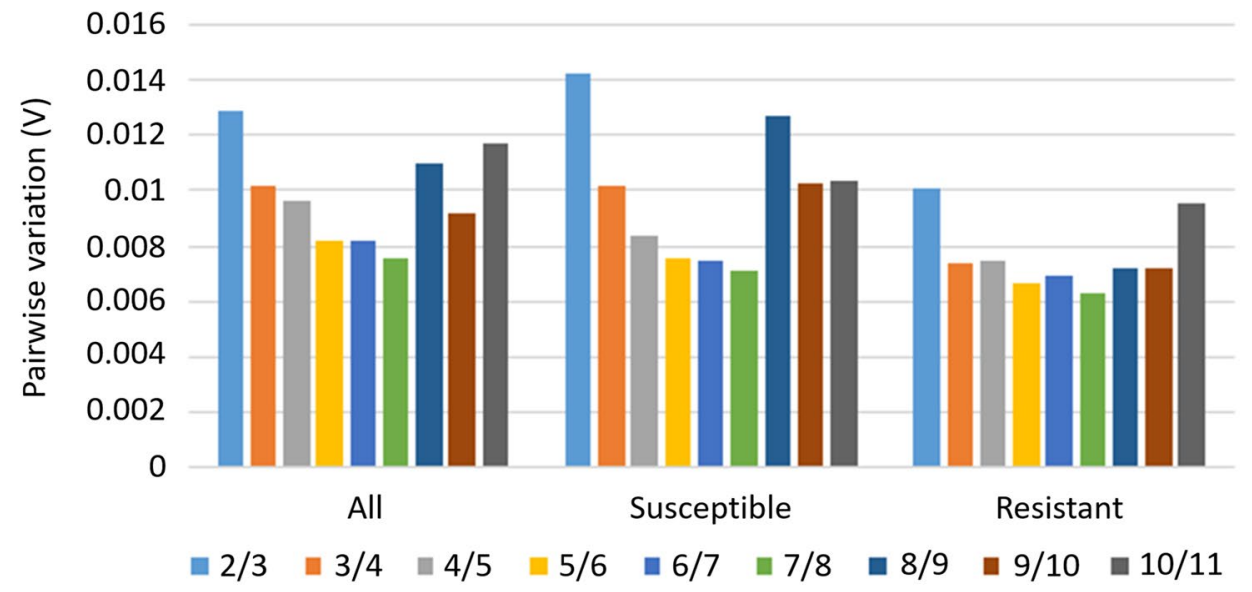

Figure 4. Determination of the optimal number of reference genes necessary for the accurate normalization in all tested samples, susceptible and resistant plant samples.

all samples, to show the differences in target genes expression between the pyroxsulam resistant and susceptible plants.

The descriptive statistics of the results obtained with TBP and GAPC used as normalizers showed that the expression of $A B C C 10$ was higher in the non-treated resistant plants than in susceptible plants (Fig. 5A). Although the change in the $A B C C 10$ expression was higher in the pyroxsulam resistant plants $1 \mathrm{~h}$ after treatment with herbicide than in the susceptible ones, however, at $24 \mathrm{~h}$ time point, the $A B C C 10$ expression rapidly rose in the susceptible plants. Similarly, the change in the CYP89A2 expression in the treated and non-treated resistant plants was higher than in the treated and non-treated susceptible ones, both at $1 \mathrm{~h}$ and $24 \mathrm{~h}$ (Fig. 5B). Moreover, the treatment with herbicide caused up-regulation of the CYP89A2 expression.

Finally, to show how important it is to choose the most stably expressed reference genes for accurate normalization, the $A B C C 10$ and $C Y P 89 A 2$ expression analyses were performed using the least stably expressed HKGs as normalizers, namely $E F 1 A$ and $U B Q$. $A B C C 10$ was expressed at the same level in the majority of experimental conditions, except for the samples from the non-treated resistant plants harvested $24 \mathrm{~h}$ after treatment with herbicide, which exhibited lower $A B C C 10$ expression than the remaining samples (Fig. 5A). The CYP89A2 expression analysis confirmed slight differences in the expressions between the resistant and susceptible plants, except for the samples from the susceptible plants harvested $24 \mathrm{~h}$ after treatment with herbicide with downregulation in CYP89A2 expression (Fig. 5B). Moreover, higher variance values calculated for each condition with the use of the most and the least stably expressed HKGs as normalizers, were observed for $E F 1 A$ and $U B Q$, which indicated greater discrepancies of the obtained results within each subset of samples after normalization (Table S3). This analysis showed that the use of inappropriate normalizers changes the final results of the target gene expression analysis. Comparison of the results obtained using the most and the least stably expressed genes for normalization showed that there was not one direction of the changes in gene expression between samples. For example, the use of the least stably expressed genes for normalization led to the results indicating downregulation of the CYP89A2 expression in the non-treated susceptible plants harvested $24 \mathrm{~h}$ after treatment with herbicide, while the normalization performed with the most stably expressed genes indicated up-regulation of the CYP89A2 expression.

\section{Discussion}

Weed resistance to herbicides poses a serious threat to world crop production. Repetitive field applications of herbicides with the same mode of action resulted in the emergence of herbicide-resistant weed populations. The herbicide resistance may be initiated by mutations in the coding sequence of the target site of the herbicide active substance or over-production of the target enzyme. The second resistance mechanism is based, among others, on the increased metabolism and detoxication of xenobiotics. In the case of A. spica-venti, which was the subject of this study, TSR has been widely examined for the presence of mutations conferring resistance to ALS inhibitors ${ }^{6,24,25}$, while the experiments concerning NTSR mechanisms at the molecular level have been scarce. $A$. spica-venti transcriptome has been recently published ${ }^{16}$, however, to study the expression of the selected genes that may be associated with herbicide resistance, an internal control (reference gene) for normalization should be applied. Reference genes use is desired for the avoidance of the errors originating from the differences in RNA integrity, starting RNA quantity between samples, reverse transcription efficiency, and primer efficiency ${ }^{18}$. Therefore, in this study, A. spica-venti HKGs expression stability analysis was performed to choose the most stably expressed reference genes for the further target gene expression analyses.

According to the statistical analyses of the efficiency corrected $\mathrm{Cq}$ values, the best genes for expression data normalization were TBP, GAPC, and CYP28. The least stably expressed genes included EF1A, UBQ, and RPL23A. However, when the plants susceptible and resistant to ALS inhibitor were analyzed separately, the genes with the most stable expression were CYP28, SPS, and TBP, GAPC, respectively. TBP is the most stably expressed gene in Lolium multiflorum under salt stress and in A. fatua under herbicide stress ${ }^{14,26}$. Moreover, TBP was indicated as 
A

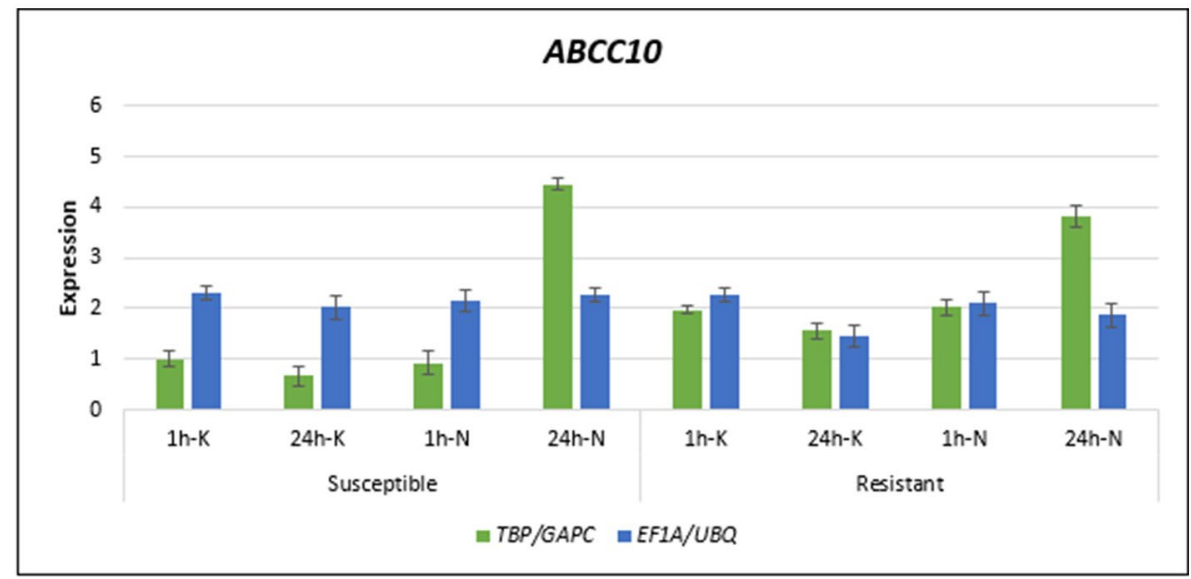

\begin{tabular}{|c|c|c|c|c|c|c|c|c|}
\hline \multirow{2}{*}{$\begin{array}{c}\text { Reference } \\
\text { gene }\end{array}$} & \multicolumn{7}{|c|}{ Standard deviation } \\
\cline { 2 - 9 } & $1 \mathrm{~h}-\mathrm{K}$ & $24 \mathrm{~h}-\mathrm{K}$ & $1 \mathrm{~h}-\mathrm{N}$ & $24 \mathrm{~h}-\mathrm{N}$ & $1 \mathrm{~h}-\mathrm{K}$ & $24 \mathrm{~h}-\mathrm{K}$ & $1 \mathrm{~h}-\mathrm{N}$ & $24 \mathrm{~h}-\mathrm{N}$ \\
\hline$T B P / G A P C$ & 0.7351 & 0.9062 & 1.1334 & 0.5343 & 0.4026 & 0.7539 & 0.6856 & 1.0952 \\
\hline EFIA/UBQ & 0.6704 & 1.1703 & 0.9941 & 0.6765 & 0.6646 & 1.0710 & 1.1003 & 1.1226 \\
\hline
\end{tabular}

B

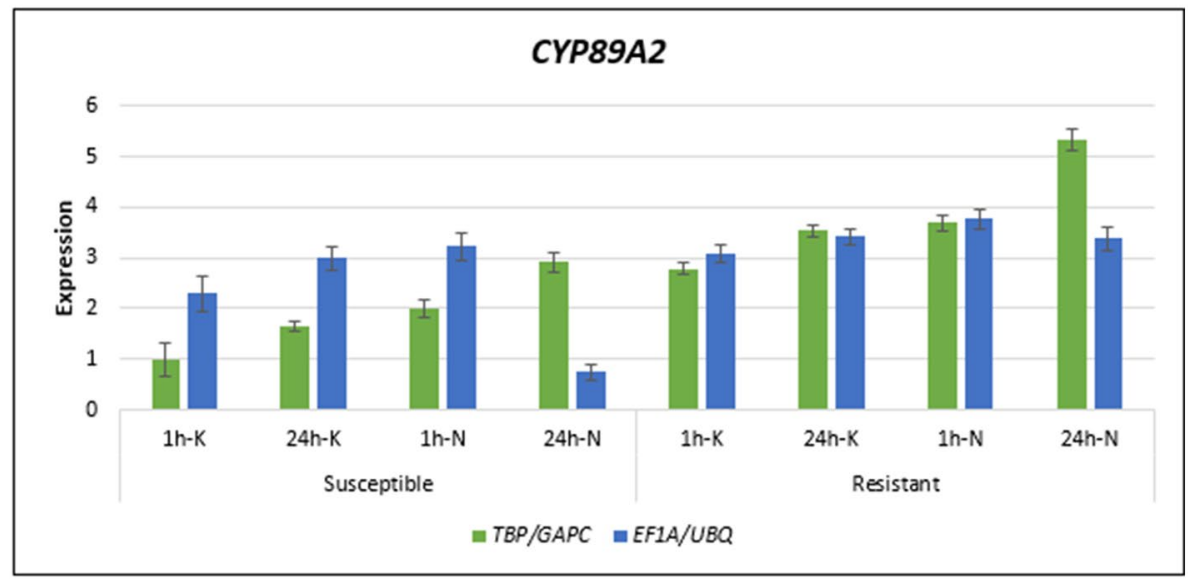

\begin{tabular}{|c|c|c|c|c|c|c|c|c|}
\hline \multirow{2}{*}{$\begin{array}{c}\text { Reference } \\
\text { gene }\end{array}$} & \multicolumn{7}{|c|}{ Standard deviation } \\
\cline { 2 - 9 } & $1 \mathrm{~h}-\mathrm{K}$ & $24 \mathrm{~h}-\mathrm{K}$ & $1 \mathrm{~h}-\mathrm{N}$ & $24 \mathrm{~h}-\mathrm{N}$ & $1 \mathrm{~h}-\mathrm{K}$ & $24 \mathrm{~h}-\mathrm{K}$ & $1 \mathrm{~h}-\mathrm{N}$ & $24 \mathrm{~h}-\mathrm{N}$ \\
\hline$T B P / G A P C$ & 1.6093 & 0.4904 & 0.9240 & 0.9497 & 0.6307 & 0.6250 & 0.7643 & 1.0862 \\
\hline$E F I A / U B Q$ & 1.73747 & 1.09923 & 1.34679 & 0.77368 & 0.76666 & 0.75868 & 1.00127 & 1.16583 \\
\hline
\end{tabular}

Figure 5. Expression of $A B C C 10$ (A) and CYP89A2 (B) in Apera spica-venti plants non-treated or treated with pyroxsulam $1 \mathrm{~h}$ and $24 \mathrm{~h}$ after treatment with herbicide. RT-qPCR results were normalized against the most stably expressed HKGs, TBP and GAPC (green bars); and the least stably expressed, EF1A and UBQ (blue bars). Bars indicate mean expression, while the whiskers represent the standard error. ABCC10 and CYP89A2 expressions were set to 1.0 value in non-treated susceptible plants harvested $1 \mathrm{~h}$ after treatment with herbicide (1h-K), while the genes' expression values in the remaining experimental conditions were adjusted accordingly. The tables below the charts represent standard deviation values calculated for the expression values of $A B C C 10$ and CYP89A2 in each condition with the use of the most stably expressed HKGs, TBP and GAPC, and the least stably expressed, $E F 1 A$ and $U B Q$, as normalizers. $1 \mathrm{~h}$ and $24 \mathrm{~h}$-time after treatment; $\mathrm{K}$-non-treated plants; $\mathrm{N}$-plants treated with pyroxsulam.

the most suitable reference gene under treatment with herbicide in Galium aparine ${ }^{27}$. GAPDH was also among the most stably expressed genes in herbicide-resistant grass species such as A. myosuroides, A. fatua, and Alopecurus japonicus ${ }^{10,14,28}$. CYP28, belonging to the cyclophilin (peptidyl-prolyl cis-trans isomerase) gene family was shown in our studies to be one of the most stably expressed reference genes. Cyclophilin was also used for normalization in Cucumis melo ${ }^{29}$, whereas, SPS was implemented as an endogenous reference gene in Oryza sativa ${ }^{30}$.

Various biotic and abiotic factors may influence housekeeping genes expression. Also, the expression stability of indicated experimentally genes might be affected in specific conditions including the plants' developmental stage, which should be taken into account when designing an experiment using reference genes for normalization.

The validation of the most and the least stably expressed reference genes showed that the selection of the inappropriate genes in normalization might lead to the incorrect results of target gene expression analysis in the 
test conditions. In our study, it was revealed that the ABCC10 expression in the pyroxsulam susceptible plants $24 \mathrm{~h}$ after herbicide application, varied substantially when normalization was carried out with the best and the worst reference genes. The use of the genes with unstable expression also led to the results indicating the opposite gene expression changes (from up- to down-regulation of the target gene expression). The analysis of $A B C C 10$, as well as CYP89A2 expression, showed the elevated expression of these genes after the treatment with herbicide, which implies their involvement in the plant's reaction to the herbicide application. ABC transporters are known for their involvement in herbicide resistance through sequestration of the herbicides and their metabolites ${ }^{21}$. $A B C C 10$ was highly expressed in the plants resistant to tribenuron-methyl M. aquaticum and indicated to play an essential role in $\mathrm{NTSR}^{22}$. By contrast, the transcriptome analysis in diclofop resistant $L$. rigidum revealed the CYP89A expression up-regulation in the resistant, non-treated with the herbicide plants ${ }^{23}$. In our results, the $A B C C 10$ expression in the untreated A. spica-venti resistant to pyroxsulam plants was higher than in susceptible plants. This implies that this gene is constitutively expressed in resistant plants at a higher level than in susceptible plants, which is consistent with previous studies of M. aquaticum. However, CYP89A2, belonging to the CYP450s gene family participating in phase I of herbicide detoxification, also exhibits the increased expression in the non-treated resistant plants at two time points, which is also in accordance with transcriptome analysis of diclofop-resistant L. rigidum.

Usually, in analyses of the expression stability of HKGs by different algorithms, no efficiency corrected Cq values have been used as an input. In such situations, the assumption of $100 \%$ primers efficiency is taken, however, in practice, such a value of primer efficiency is not always achievable. Our results show that the implementation of the efficiency corrected input data changed the gene's positions in the expression stability rankings, therefore it is important to consider the efficiency correction of the raw input data. This issue has also been brought up by another study, which indicated the necessity of performing efficiency correction of the results obtained in RTqPCR with primers exhibiting efficiencies differing by more than $10 \%$ from the optimal $100 \%{ }^{15}$.

\section{Materials and methods}

Plant material. Firstly, eleven populations of A. spica-venti found on Polish fields, susceptible and resistant to pyroxsulam N-(5,7-dimethoxy[1,2,4]triazolo[1,5-a]pyrimidin-2-yl)-2-methoxy4-(trifluoromethyl)pyridine3-sulfonamide (ALS inhibitors) were examined to determine ED50. Seeds were sown in the pots placed under controlled conditions in the greenhouse. Plants at the $\mathrm{BBCH} 12-13$ stage were treated with the following herbicide Nomad 75 WG (ai pyroxsulam $75 \mathrm{~g} \mathrm{~kg}^{-1}$, DOW AGROSCIENCES, Corteva Agriscience, Wilmington, USA) at the doses: for resistant populations: $0 \mathrm{~N}, 0.5 \mathrm{~N}, 1 \mathrm{~N}, 2 \mathrm{~N}, 4 \mathrm{~N}, 8 \mathrm{~N}, 16 \mathrm{~N}, 32 \mathrm{~N}$; for susceptible populations: $0 \mathrm{~N}$, $1 / 16 \mathrm{~N}, 1 / 8 \mathrm{~N}, 1 / 4 \mathrm{~N}, 1 / 2 \mathrm{~N}, 1 \mathrm{~N}, 2 \mathrm{~N}, 4 \mathrm{~N}$; where $\mathrm{N}$-the maximal recommended dose of the herbicide $\left(120 \mathrm{~g} \mathrm{ha}^{-1}\right.$, i.e. $9 \mathrm{~g} \mathrm{ha}^{-1}$ of active substance). Based on the obtained results, plants from the selected susceptible and resistant populations were scanned for the presence of mutations in the ALS sequence in order to choose populations without mutations in the ALS gene, which are known to confer the resistance.

Thereafter, the four chosen populations of $A$. spica-venti plants were used in the reference gene analysis experiment: two susceptible and two resistant to pyroxsulam (Nomad 75 WG). Plants at the BBCH $12-13$ stage were treated or non-treated with the recommended dose of the herbicide $\left(120 \mathrm{~g} \mathrm{ha}^{-1}\right)$ and harvested at $1 \mathrm{~h}$ and $24 \mathrm{~h}$ after treatment. Four biological replicates for each condition, with 2 plants per replicate, were frozen in the liquid nitrogen. All samples were stored at $-80^{\circ} \mathrm{C}$ until RNA extraction.

The use of plants in the present study complies with the IUCN Policy Statement on Research Involving Species at Risk of Extinction and the Convention on the Trade in Endangered Species of Wild Fauna and Flora.

DNA isolation and ALS sequence analysis. Plant material was ground in a mortar using liquid nitrogen. Genomic DNA was isolated using NucleoSpin Plant II, Mini kit for DNA from plants (Mecherey-Nagel, Düren, Germany). PCR to amplify A. spica-venti ALS sequence was carried out in $50 \mu \mathrm{l}$ reaction mixture containing $1 \times$ Q5 Reaction Buffer (NEB, Ipswich, MA, USA), $200 \mu \mathrm{M}$ dNTPs, $0.5 \mu \mathrm{M}$ forward primer (5' ATG GCCACAGCCACGTCCA 3'), $0.5 \mu \mathrm{M}$ reverse primer (5' ATAAGAAAYCCTGCCATCACCKTC 3'), $200 \mathrm{ng}$ of genomic DNA, and $1 \mathrm{U}$ of Q5 High-Fidelity DNA Polymerase (NEB). PCR was performed in a Mastercycler nexus (Eppendorf, Hamburg, Germany) with an initial denaturation at $98^{\circ} \mathrm{C}$ for $30 \mathrm{~s}$, followed by 35 cycles of amplification: $10 \mathrm{~s}$ at $98^{\circ} \mathrm{C}, 30 \mathrm{~s}$ at a $63.3^{\circ} \mathrm{C}$, and $30 \mathrm{~s}$ at $72{ }^{\circ} \mathrm{C}$, with a final step of $2 \mathrm{~min}$ at $72{ }^{\circ} \mathrm{C}$. The reactions' products were separated with $1 \%$ gel electrophoresis, purified from the gel with Wizard SV Gel and PCR Clean-Up System (Promega, Madison, WI, USA), ligated to pJET1.2 plasmid using CloneJET PCR Cloning Kit (Thermo Fisher Scientific, Waltham, MA, USA), and cloned into DH10B Escherichia coli competent cells. The plasmids were isolated from E. coli cells using NucleoSpin ${ }^{\circ}$ Plasmid (Mecherey-Nagel). Three plasmids were sequenced per one plant. The presence of the insert in plasmids was confirmed by the digestion with BglII. DNA inserts were sequenced by Genomed (Warsaw, Poland). Sequencing data were analyzed using the BioEdit Sequence Alignment Editor 7.5.5

RNA extraction and CDNA synthesis. Plant material was ground in a mortar using liquid nitrogen. Total RNA was extracted using $500 \mu \mathrm{l}$ of TriReagent solution (Thermo Fisher Scientific) followed by RNA precipitation with 2-propanol. The precipitate was washed with $70 \%$ ethanol, air-dried, and suspended in nucleasefree water. The RNA concentration and purity (the $260 \mathrm{~nm} / 230 \mathrm{~nm}$ and $260 \mathrm{~nm} / 280 \mathrm{~nm}$ values) of each sample were estimated using a NanoDrop ND-2000 spectrophotometer (Thermo Fisher Scientific).

Total RNA $(2.5 \mu \mathrm{g})$ was reverse transcribed using Maxima First Strand cDNA Synthesis Kit for RT-qPCR with dsDNase (Thermo Fisher Scientific). The cDNA samples were diluted with $30 \mu$ of nuclease-free water. 
Gene selection, primer design, and RT-qPCR. Eleven candidate reference genes were selected for the analysis: ACT, ARF1, CYP28, EF1A, GAPC, RPL23A, RCA, SPS, TBP, UBC, and UBQ. Moreover, 2 genes associated with NTSR were chosen for validation: encoding the ABC transporter C family member 10-like (ABCC10) and cytochrome P450 89A2 (CYP89A2). Primers sequences were designed based on the A. spica-venti published transcriptome (NCBI Gene Expression Omnibus GSE86989) ${ }^{16}$ using Primer3 software (version 0.4.0) ${ }^{32}$. Primers sequences list is presented in Table 1.

RT-qPCR was performed in $10 \mu \mathrm{l}$ solution containing $1 \times$ iTaq Universal SYBR Green Supermix (Bio-Rad, Hercules, USA), $0.5 \mu \mathrm{M}$ forward primer, $0.5 \mu \mathrm{M}$ reverse primer, and $1 \mu \mathrm{l} \mathrm{cDNA}$. The PCR program consisted of an initial incubation step at $95^{\circ} \mathrm{C}$ for $3 \mathrm{~min}$, followed by 40 cycles of $95^{\circ} \mathrm{C}$ for $15 \mathrm{~s}$, an annealing step for $30 \mathrm{~s}$ (temperatures listed in Table 1), and $72{ }^{\circ} \mathrm{C}$ for $30 \mathrm{~s}$. The dissociation curves were generated from 60 to $95^{\circ} \mathrm{C}$. The standard curve for each gene was made on the basis of $n$-fold dilutions of cDNA. Reactions were performed in triplicate (technical replicates) in QuantStudio5 (Thermo Fisher Scientific). However, to optimize reactions' conditions for each pair of primers, firstly RT-qPCR with temperature gradient at the annealing step was performed. To confirm the estimated size of the amplicons, the reactions' products were resolved on a $2 \%$ agarose gel, purified from the gel with Wizard SV Gel and PCR Clean-Up System (Promega), ligated to pJET1.2 plasmid using CloneJET PCR Cloning Kit (Thermo Fisher Scientific), and cloned into DH10B Escherichia coli competent cells. The plasmids were isolated from E. coli cells using NucleoSpin Plasmid (Mecherey-Nagel), followed by the confirmation of insert presence in plasmids by the digestion with BglII. DNA inserts were sequenced by Genomed (Warsaw, Poland). Sequencing data were analyzed using the BioEdit Sequence Alignment Editor 7.5.5 $5^{31}$. The obtained sequences were compared with sequences of the corresponding transcript in A. spica-venti transcriptome and submitted to the GenBank database. To confirm the similarity of the sequences of products amplified by the designed primers targeting HKGs encoding genes to the selected genes, they were blasted to the following databases: NCBI blastn and UniProt blastp. Moreover, the sequences were blasted against a model plant species A. thaliana TAIR database (Araport11 Proteins) using the website BLASTP search (version 2.9.0+, https://www.arabidopsis.org/Blast/index.jsp) and against the closest to A. spica-venti model plant species $B$. distachyon protein sequences (v3.2) (3) $^{33}$ downloaded from Phytozome ${ }^{34}$ using OmicsBox ${ }^{35}$.

Data analysis and validation. Distribution of candidate reference genes Cq, efficiency correction of Cq data as well as the normalization of the expression of CYP89A2 and ABCC10 using the most and the least stably expressed genes were performed with GenEx (version 6.1.1.550, Multid Analyses AB, Göteborg, Sweden). The expression of CYP89A2 and ABCC10 was calculated using descriptive statistics at the confidence level of $95 \%$.

To determine the expression stability of the reference gene candidates for A. spica-venti, the analyses were carried out using four independent bioinformatics algorithms: geNorm ${ }^{17}$ and BestKepeer ${ }^{18}$ softwares, performed in the integrated development environment (IDE) of R (RStudio), NormFinder software ${ }^{19}$ in GenEx (version 6.1.1.550), and $\Delta \mathrm{Ct}$ method ${ }^{20}$ recalculated in Microsoft Excel application (Microsoft Office 2018). To gain a comprehensive list of genes expression stability by calculating the geometric mean, RefFinder software (https:// www.heartcure.com.au/reffinder) was implemented. The analyses were performed using pooled Cq data from susceptible and resistant samples together, pooled Cq values for the susceptible samples only, and separately for the resistant samples only.

To conduct genes expression stability analysis in the R software environment, the data from RT-qPCR analysis (non-corrected or efficiency corrected Cq values) were loaded to R software (version 3.6.2) " $^{36}$. To conduct expression stability analysis of the selected candidate genes, two different packages were installed: "NormqPCR" (version 1.7.1) $)^{37}$ (geNorm) and "ctrlGene" (version 1.0.1) ${ }^{38}$ (BestKeeper). The first one calculates the average expression stability values $(\mathrm{M})$ of the analyzed genes during stepwise exclusion of the least stably expressed genes in each round until the most stably expressed candidates remain. The second one calculates descriptive statistics from $\mathrm{Cq}$ data and pairwise correlation between all analyzed genes. The results of gene expression stability analysis from BestKeeper software are calculated given the standard deviation (SD) of Cq values between all analyzed genes, where the lowest SD score represents the gene with the most stable expression in ranking index ${ }^{37}$. In order to determine the minimum required number of reference genes for the analysis, the algorithm in geNorm calculates the pairwise variation $\left(V_{n / n+1}\right)$ between the two sequential normalization factors $\left(\mathrm{NF}_{n}\right.$ and $\left.\mathrm{NF}_{\mathrm{n}+1}\right)$ with the cut-off threshold of $0.15^{38}$.

The NormFinder software calculates a global average expression of all genes in the model studied, to which the individual genes are compared. Next, the SD is estimated for each candidate gene and separates the variation into intragroup and intergroup contribution ${ }^{19}$. The $\Delta \mathrm{Ct}$ method calculates the expression stability of individual genes by comparing the relative expression of two reference genes pairwise. At the first step, the delta Cq is estimated between each pair of tested genes with the SD values of the obtained results. Then, a fixed base index of $\mathrm{SD}$ values for each tested-gene with its all possible pair is generated. The expression stability of candidate genes is ranked according to the mean values of SD recalculated for each index ${ }^{20}$.

Consent for publication. All authors have consented to this publication.

\section{Data availability}

All data generated or analyzed during this study are included in this published article.

Received: 23 March 2021; Accepted: 1 November 2021

Published online: 12 November 2021 


\section{References}

1. GBIF Secretariat. Apera spica-venti P. Beauv. GBIF Backbone Taxonomy. Checklist Dataset (2019). www.GBIF.org (Accessed 20 February 2021).

2. Adamczewski, K., Kaczmarek, S., Kierzek, R. \& Matysiak, K. Significant increase of weed resistance to herbicides in Poland. J. Plant Prot. Res. 59, 139-150 (2019).

3. Soukup, J., Novakova, K., Hamouz, P. \& Namestek, J. Ecology of silky bent grass (Apera spica-venti (L.) Beauv.), its importance and control in the Czech Republic. J. Plant Dis. Prot. 20, 73-80 (2006).

4. Hamouzová, K. et al. Cross-resistance to three frequently used sulfonylurea herbicides in populations of Apera spica-venti from the Czech Republic. Weed Res. 51, 113-122 (2011).

5. Babineau, M. et al. Spatial distribution of acetolactate synthase resistance mechanisms in neighboring populations of silky windgrass (Apera spica-venti). Weed Sci. 65, 479-490 (2017).

6. Massa, D., Krenz, B. \& Gerhards, R. Target-site resistance to ALS-inhibiting herbicides in Apera spica-venti populations is conferred by documented and previously unknown mutations. Weed Res. 51, 294-303 (2011).

7. Powles, S. B. \& Yu, Q. Evolution in action: Plants resistant to herbicides. Annu. Rev. Plant Biol. 61, 317-347 (2010).

8. Délye, C. Unravelling the genetic bases of non-target-site-based resistance (NTSR) to herbicides: A major challenge for weed science in the forthcoming decade. Pest Manage. Sci. 69, 176-187 (2013).

9. Gaines, T. A. et al. Mechanisms of evolved herbicide resistance. J. Biol. Chem. 295, 10307-10330 (2020).

10. Petit, C., Pernin, F., Heydel, J.-M. \& Délye, C. Validation of a set of reference genes to study response to herbicide stress in grasses. BMC Res. Notes 5, 1-10 (2012).

11. Chen, J. et al. Selection of relatively exact reference genes for gene expression studies in goosegrass (Eleusine indica) under herbicide stress. Sci. Rep. 7, 1-9 (2017).

12. Thellin, O. et al. Housekeeping genes as internal standards: Use and limits. J. Biotechnol. 75, 291-295 (1999).

13. Duhoux, A. \& Délye, C. Reference genes to study herbicide stress response in Lolium sp.: Up-regulation of P450 genes in plants resistant to acetolactate-synthase inhibitors. PLOS ONE 8, e63576 (2013).

14. Wrzesińska, B., Kierzek, R. \& Obrępalska-Stęplowska, A. Evaluation of six commonly used reference genes for gene expression studies in herbicide-resistant Avena fatua biotypes. Weed Res. 56, 284-292 (2016).

15. De Spiegelaere, W. et al. Reference gene validation for RT-qPCR, a note on different available software packages. PLoS ONE 10, e0122515 (2015).

16. Babineau, M., Mahmood, K., Mathiassen, S. K., Kudsk, P. \& Kristensen, M. D. novo transcriptome assembly analysis of weed Apera spica-venti from seven tissues and growth stages. BMC Genom. 18, 1-12 (2017).

17. Vandesompele, J. et al. Accurate normalization of real-time quantitative RT-PCR data by geometric averaging of multiple internal control genes. Genome Biol. 3, 1-12 (2002).

18. Pfaffl, M. W., Tichopad, A., Prgomet, C. \& Neuvians, T. P. Determination of stable housekeeping genes, differentially regulated target genes and sample integrity: BestKeeper-Excel-based tool using pair-wise correlations. Biotechnol. Lett. 26, 509-515 (2004).

19. Andersen, C. L., Jensen, J. L. \& Ørntoft, T. F. Normalization of real-time quantitative reverse transcription-PCR data: A model-based variance estimation approach to identify genes suited for normalization, applied to bladder and colon cancer data sets. Cancer Res. 64, 5245-5250 (2004).

20. Silver, N., Best, S., Jiang, J. \& Thein, S. L. Selection of housekeeping genes for gene expression studies in human reticulocytes using real-time PCR. BMC Mol. Biol. 7, 1-9 (2006).

21. Yuan, J. S., Tranel, P. J. \& Stewart, C. N. Jr. Non-target-site herbicide resistance: A family business. Trends Plant. Sci. 12, 6-13 (2007).

22. Liu, W. et al. Non-target site-based resistance to tribenuron-methyl and essential involved genes in Myosoton aquaticum (L.). BMC Plant Biol. 18, 1-14 (2018).

23. Gaines, T. A. et al. RNA-Seq transcriptome analysis to identify genes involved in metabolism-based diclofop resistance in Lolium rigidum. Plant J. 78, 865-876 (2014).

24. Krysiak, M., Gawroński, S., Adamczewski, K. \& Kierzek, R. ALS gene mutations in Apera spica-venti confer broad-range resistance to herbicides. J. Plant Prot. Res. 51, 261 (2011).

25. Hamouzová, K., Košnarová, P., Salava, J., Soukup, J. \& Hamouz, P. Mechanisms of resistance to acetolactate synthase-inhibiting herbicides in populations of Apera spica-venti from the Czech Republic. Pest Manage. Sci. 70, 541-548 (2014).

26. Wang, X., Ma, X., Huang, L. \& Zhang, X. Identification of the valid reference genes for quantitative RT-PCR in annual ryegrass (Lolium multiflorum) under salt stress. Molecules 20, 4833-4847 (2015).

27. Su, X. et al. Reference gene selection for quantitative real-time PCR (qRT-PCR) expression analysis in Galium aparine L.. PLoS ONE 15, e0226668 (2020).

28. Xu, H. et al. Identification of reference genes for studying herbicide resistance mechanisms in Japanese foxtail (Alopecurus japonicus). Weed Sci. 65, 557-566 (2017).

29. Qin, X., Coku, A., Inoue, K. \& Tian, L. Expression, subcellular localization, and cis-regulatory structure of duplicated phytoene synthase genes in melon (Cucumis melo L.). Planta 234, 737-748 (2011).

30. Ding, J. et al. Validation of a rice specific gene, sucrose phosphate synthase, used as the endogenous reference gene for qualitative and real-time quantitative PCR detection of transgenes. J. Agric. Food Chem. 52, 3372-3377 (2004).

31. Hall, T. A. BioEdit: A user-friendly biological sequence alignment editor and analysis program for Windows 95/98/NT. Nucleic Acids Symp. Ser. 41, 95-98 (1999).

32. Misener, S. \& Krawetz, S. A. (eds) Bioinformatics Methods and Protocols 365-386 (Springer, 2000).

33. The International Brachypodium Initiative. Genome sequencing and analysis of the model grass Brachypodium distachyon. Nature 463, 763-768 (2010).

34. Goodstein, D. M. et al. Phytozome: A comparative platform for green plant genomics. Nucleic Acids Res. 40, D1178-D1186 (2012).

35. Götz, S. et al. High-throughput functional annotation and data mining with the Blast2GO suite. Nucleic Acids Res. 36, 3420-3435 (2008).

36. R Core Team. R: A language and environment for statistical computing. In: R Foundation for Statistical Computing (2015)

37. Perkins, J. R. et al. ReadqPCR and NormqPCR: R packages for the reading, quality checking and normalisation of RT-qPCR quantification cycle (Cq) data. BMC Genom. 13, 1-8 (2012).

38. Zhong, S. ctrlGene: Assess the stability of candidate housekeeping genes. R Package Version 1.0.1 (2019).

\section{Acknowledgements}

This study was supported by Grant BIOSTRATEG/3/347445/1/NCBR/2017 funded by The Polish National Centre for Research and Development.

\section{Author contributions}

A.O.S. conceptualisation. A.O.S. and B.W. designed the experiment and methodology of the analysis. T.P. provided samples of weed populations. B.W. and P.F. collected samples. K.K. and B.W. performed RNA isolation, 
reverse transcription, and RT-qPCR. B.W., A.O.S. and P.F. wrote the manuscript. B.W. and P.F. analysed RT-qPCR data. A.O.S. and T.P. revised the manuscript. All authors read and approved the final manuscript.

\section{Competing interests}

The authors declare no competing interests.

\section{Additional information}

Supplementary Information The online version contains supplementary material available at https://doi.org/ 10.1038/s41598-021-01615-6.

Correspondence and requests for materials should be addressed to A.O.-S.

Reprints and permissions information is available at www.nature.com/reprints.

Publisher's note Springer Nature remains neutral with regard to jurisdictional claims in published maps and institutional affiliations.

(c) (i) Open Access This article is licensed under a Creative Commons Attribution 4.0 International License, which permits use, sharing, adaptation, distribution and reproduction in any medium or format, as long as you give appropriate credit to the original author(s) and the source, provide a link to the Creative Commons licence, and indicate if changes were made. The images or other third party material in this article are included in the article's Creative Commons licence, unless indicated otherwise in a credit line to the material. If material is not included in the article's Creative Commons licence and your intended use is not permitted by statutory regulation or exceeds the permitted use, you will need to obtain permission directly from the copyright holder. To view a copy of this licence, visit http://creativecommons.org/licenses/by/4.0/.

(C) The Author(s) 2021 